Table 2. Time constant $1 / s_{1}$ for turbulent flow

\begin{tabular}{lccc} 
& \multicolumn{3}{c}{$1 / s_{1}\left(1 \mathrm{~d}^{-1}\right)$} \\
$\mathrm{m} \backslash \alpha$ & $10^{-2}$ & $10^{-3}$ & $10^{-4}$
\end{tabular}

\begin{tabular}{clll}
\hline & & & \\
0.05 & 0.011 & $3.3 \times 10^{-4}$ & $1.1 \times 10^{-5}$ \\
0.1 & 0.017 & $5.3 \times 10^{-4}$ & $1.7 \times 10^{-5}$ \\
1 & 0.078 & $2.5 \times 10^{-3}$ & $7.8 \times 10^{-5}$ \\
10 & 0.36 & 0.011 & $3.6 \times 10^{-4}$ \\
100 & 1.7 & 0.053 & $1.7 \times 10^{-3}$ \\
& & & \\
\hline
\end{tabular}

Note. $n$ equals 0.022 (SI). Tables apply to a horizontal bed.

Walder's second conclusion that a downstream decrease in $\alpha$ can be accommodated by an increase in channel cross-sectional area $S$ is, of course, normally true. However, one can easily construct examples where this is not true. For these cases, a solution is obtained if a water sheet exists over one or more reaches. Walder's conclusion is incorrect.

Regarding Walder's third point that I ignored, plastic closure and other effects in predicting the hydrograph, this matter was better dealt with by Shoemaker (1992b) in which an argument was given for crudely estimating the duration of a flood. No hydrographic analysis was made because I have concluded that a meaningful analysis cannot be produced. Not enough is known, for example, about the mega subglacial lake that feeds a mega flood (Shoemaker, 1991).

Department of Applied Mathematics,

E. M. SHOEMAKER

Simon Fraser University,

Burnaby, British Columbia V5A 1S6, Canada

\section{August 1993}

\section{REFERENCES}

Paterson, W. S. B. 1981. The physics of glaciers. Second edition. Oxford, etc., Pergamon Press.

Shoemaker, E. M. 1991. On the formation of large subglacial lakes. Can. 7. Earth Sci., 28(12), 1975-1981.

Shoemaker, E. M. 1992a. Subglacial floods and the origin of low-relief ice-sheet lobes. F. Glaciol., 38(128), 105-112.

Shoemaker, E. M. 1992b. Water sheet outburst floods from the Laurentide ice sheet. Can. 7. Earth Sci., 29(6), 1250-1264.

Walder, J. S. 1982. Stability of sheet flow of water beneath temperate glaciers and implications for glacier surging. F. Glaciol., 28(99), 273293.

Walder, J.S. 1994. Comments on "Subglacial floods and the origin of low-relief ice-sheet lobes" by E. M. Shoemaker. F. Glaciol., 40(134), 199-200.

The accuracy of references in the text and in this list is the responsibility of the author, to whom queries should be addressed.
SIR,

\section{Comments on "Analysis of glacier facies using satellite} techniques" by Williams and others

A scheme of zones (facies) for glaciers, suggested by Benson $(1959,1961)$ and Müller $(1962)$, was intended to cover all zones (facies) of glaciers anywhere in the world. This included ablation (ice) facies, superimposed-ice zone, slush zone, soaked (wet-snow) facies, percolation facies and dry-snow facies.

A Landsat 5 TM image (24 August 1986) of Brúarjökull, an outlet glacier from the Vatnajökull ice cap, east Iceland, was the source of a study by Williams and others (1991), from which they arrived at a revised scheme for glacier facies from remotely sensed data. Figures 5 and 6 in that paper show that there is a distinct difference of reflectance between areas on Brúarjökull on the above-mentioned date but, in the absence of direct and simultaneous ground observation, most of their physical properties remain speculative.

Williams and others (1991) pointed out that "the upper limit of wet snow corresponds approximately with the $1300 \mathrm{~m}$ contour line". By this, they did not imply the wet-snow facies, but this could have been misunderstood. As stated in the paper, there is no dry-snow facies on Vatnajökull and percolation facies cannot be detected on Landsat images. Rist (1961) and Theodórsson (1970) measured the temperature in drillholes at 1614, 1730 and $2000 \mathrm{~m}$ a.s.l. on the Vatnajökull ice cap and found that the glacier is temperate. Accordingly, there can be no upper limit to the wet-snow facies. This has been confirmed by Icelandic glaciologists during the cooling that started about 30 years ago. Generally, there are only two facies present on temperate glaciers, namely, ice facies and wet-snow facies. The presence of a slush zone would necessarily have to be confirmed by ground observation, but in this case it is absent.

Williams and others (1991) found that the transient snow-line is located between 1000 and $1100 \mathrm{~m}$ a.s.l. for most of the glacier. This might conceivably be correct, as there is a sharp contrast in the image at that elevation but it seems rather low for an ordinary year. However, another reason for that contrast might be the thin crust of porous ice (up to $10 \mathrm{~cm}$ thick) that is commonly superimposed on glacier ice over large areas on bright days in summer (probably condensed moisture from the atmosphere), giving the glacier an almost white appearance. Another type of white crust termed "weathering crust" has been described by Müller and Keeler (1969). These two different types of crust can probably be differentiated from snow on some bands in the satellite image.

Williams and others (1991) claimed to have found a slush zone immediately above the intended transient snow-line bordered up-glacier by the slush limit. As temperate glaciers above the equilibrium line are all within the wet-snow zone, there is no fine-grained snow in late summer that can be saturated with water. Consequently, there is usually no slush on Icelandic glaciers in late summer. This agrees with the experience of the numerous "Jeep" enthusiasts who travel all over the glaciers at all seasons of the year. An exception might be 
due to heavy snowfall during the summer or an exceptionally cold summer. According to weather records, neither is the case for the summer of 1986 in Iceland.

Furthermore, Williams and others (1991) estimated the freezing level between 1300 and $1350 \mathrm{~m}$ elevation. This is found by extrapolating temperature about $1000 \mathrm{~m}$ up and $80 \mathrm{~km}$ horizontally from the nearest weather station at $0900 \mathrm{~h} \mathrm{UT,} 3 \mathrm{~h}$ before the overpass of Landsat 5. During those $3 \mathrm{~h}$, a temperature rise of the order of $3^{\circ} \mathrm{C}$ is to be expected and thus most of the surface of the glacier in question could be above the freezing point. Secondly, the freezing level from radiosonde data more than $300 \mathrm{~km}$ distant was used to establish the freezing level on the glacier. This estimate cannot be considered reliable. However, it may not be easy to find an alternative explanation to the sharp contrast in the image in question at about $1300 \mathrm{~m}$ altitude. It might have been the freezing limit, in spite of the temperature measurements at the nearest weather station.

Orkustofnun,

ODDUR SIGURĐSSON
Grensásvegi 9,

IS-108 Reykjavik, Iceland

2 November 1992

\section{REFERENCES}

Benson, C.S. 1959. Physical investigation on the snow and firn of northwest Greenland: 1951, 1953 and 1954. SIPRE Res. Rep. 26.

Benson, C.S. 1961. Stratigraphic studies in the snow and firn of the Greenland ice sheet. Folio Geogr. Dan., 9, 13-37.

Muller, F. 1962. Zonation in the accumulation area of the glaciers of Axel Heiberg Island, N.W.T., Canada. J. Glaciol., 4(33), 302-311.

Müller, F. and C.M. Keeler. 1969. Errors in short-term ablation measurements on melting ice surfaces. f. Glaciol., 8(52), 91-105.

Rist, S. 1961. Rannsóknir á Vatnajökli 1960. Jökull, 11, 1-11.

Theodórsson, P. 1970. Rannsóknir á Bárðarbungu 1969 og 1970. Jökull, 20, 1-14.

Williams, R. S., Jr, D. K. Hall and C. S. Benson. 1991. Analysis of glacier facies using satellite techniques. F. Glaciol., 37(125), 120-128.

The accuracy of references in the text and in this list is the responsibility of the author, to whom queries should be addressed.

\section{ERRATA}

Vol. 39, No. 132, p. 381

The penultimate paragraph in column b should read:

Bamber (1987) has shown that the IRH level in twolayered glaciers on Spitsbergen is well described by the piezometric surface of Röthlisberger channels (Röthlisberger, 1972). The IRHs themselves, which were observed in spring before the melting season, are hypothesized to be the residues of a large-scale network of conduits which drain the surface meltwaters to one or more channels at depth. Some of these are closed off in the winter and water is trapped in cavities which remain in the ice at the melting-point temperature (Bamber, 1988). 